\title{
Growth and Yield Effects of Vermicompost and Vermicompost Rubbish on Selected Vegetable Crop
}

\author{
K. Sundararasu* \\ P.G. and Research Department of Zoology, Arignar Anna Government Arts College \\ Musiri-621 211, Tiruchirappalli District, Tamil Nadu, India \\ *Corresponding author
}

A B S T R A C T

\begin{abstract}
Keywords
Earthworm,

Biofertilizer,

Vermicompost,

Vermicompost

Rubbish, Tomato

crop, Soil health

Article Info

Accepted:

10 January 2019

Available Online:

10 February 2019

In today's era, heavy doses of chemical fertilizers and pesticides are being used by the farmers to get a better yield of various field crops. These chemical fertilizers and pesticides decreased soil fertility and caused health problems to the consumers. The present study was conducted to evaluate the effect of vermicompost and their biproduct vermicompost rubbish on growth and yield of tomato on various time durations. Physico-chemical properties of the soil in both control and experimental plots were studied and interrupted with results. Plant growth (height), number leaves per plant, number of flower and fruits were also recorded. 50:50 ratio vermicompost and vermicompost rubbish applied plats showed increased growth, number of leaves, flower and fruits when compared to control other ratios (40:60 and 60:40) of vermi end products. Significant yield was recorded on vermicompost applied plants than vermicompost rubbish, that vermicompost is more favorable for vital production of tomato. The vermi end products can be economically and environmentally suitable and also maintenance of agricultural soil environment.
\end{abstract}

\section{Introduction}

The United Nation's Food and Agriculture Organization (FAO) estimates that the total demands for agricultural production will be 60 percent higher in 2030 A.D. than in the present time. Of this, $85 \%$ of this additional demand will come in developing countries. In recent years, earthworm has been identified as one of the important organisms to process the biodegradable organic matter. Vermicomposts have consistently improved seed germination, enhanced seedling growth and development, increased plant flowering, fruiting and productivity much more than could be possible from the mere conversion of mineral nutrients into plant - available forms (Atiyeh et al., 2002). Vermiculture technology, an alternative of energy efficient recycling process with high nitrogen $(\mathrm{N})$, phosphorous $(\mathrm{P})$ and potassium $(\mathrm{K})$ contents, and used as quality manure in agriculture and horticulture sectors. In today's era, heavy doses of chemical fertilizers and pesticides are being used by the farmers to get a better yield of various field crops. These chemical fertilizers 
and pesticides decreased soil fertility and caused health problems to the consumers. Due to adverse effects of chemical fertilizers, interest has been stimulated for the use of organic manures (Follet et al., 1981). The use of organic matter such as animal manures, human waste, food wastes, yard wastes, sewage sludge's and composts has long been recognized in agriculture as beneficial for plant growth and yield and the maintenance of soil fertility. Organic matters are excellent source of plant-available nutrients and their addition to soil could maintain high microbial populations and activities (Joshi and Pal Vig, 2010). Earthworms are considered as friends of farmers and hold them in high esteem as nature's ploughmen. Earthworms are major macro fauna of soil and they have ability to improve soil structure. Vermicompost have particulate structure, good moisture holding capacity and contain macro and micro nutrients (Lavelle and Martin, 1992). In view of the above facts an attempt has been made to study the growth and yielding pattern of tomato by using Vermicompost and vermicompost rubbish.

\section{Materials and Methods}

Fresh cow dung and organic waste collected from Vadugapatti village $\left(10^{\circ} 45^{\prime}\right.$ to $30^{\circ} 16^{\prime}$ $\mathrm{N}$ and $78^{\circ} 70^{\prime}$ to $27^{\circ} 38^{\prime} \mathrm{E}$ ), Musiri Taluk, Tiruchirappalli District, India. they spread over clean terrain and allowed for 10 to 15 days, they thoroughly mixed with one another and mixture was prepared in three different concentrations i.e., 40:60 (40\% cow dung and $60 \%$ organic wastes); 50:50 (50\% cow dung and $50 \%$ organic wastes) and 60:40 (60\% cow dung and $40 \%$ organic wastes) and control (cow dung only) also maintained and kept in clean shadow place, water sprinkled every day to keep maintain the moisture.

After decomposition, they filled in separate cement tanks size (Size $3 \mathrm{~m} \times 6 \mathrm{~m} \times 3 \mathrm{~m}$ ) in triplicates and 50 number of adult Eudrilus eugeniae was inoculated. After 4 weeks, endproduct collected and sieved by $3 \mathrm{~mm}$ mesh. The separated vermicompost and vermicompost rubbish (sieved out matter) were collected and stored in cool and dry place for further experiments.

The pH, Electrical Conductivity (EC), Moisture, Organic Carbon, determined as suggested by Tandon (2005), Total Nitrogen determined by Micro Kjeldahl method, Total Phosphorous determined by Spectrophotometric method, Total Sulphur estimated as suggested by Tandon (2005). Determination of Total Sodium and Total Potassium by Flame Photometric Method, Estimation of Total Calcium and Magnesium by Versenate method.

Experiment was conducted at wet lab in Arignar Anna Government Arts College, Musiri, Tamil Nadu, India. Experimental plot was design $5 \mathrm{~m} \times 5 \mathrm{~m}$ area, the unwanted plants were removed, soil nutrients were analysed before and after cultivation of crops. Control plot was maintain for tomato crop.

In experimental plot the selected vegetable crop namely, Tomato (Lycopersicon pimpinellfolium) was planted in each 20 numbers both in control and each experimental plots, experimental plot I (40:60 vermicompost), experimental plots II (50:50 vermicompost), experimental plot III (60:40 vermicompost) and experimental plot IV (40:60 vermicompost rubbish), Experimental Plot V (50:50 vermicompost rubbish), experimental plot VI (60:40 vermicompost rubbish), experimental plot VII (vermicompost control).

Experimental Plot VIII (vermicompost rubbish control). The necessary data were obtained from appropriated interval and they described in results. 


\section{Results and Discussion}

$\mathrm{pH}$ was recorded with slightly acidic condition in control, 40:60 and neutral $\mathrm{pH}$ was observed in 50:50, 60:40 concentration, the Electrical Conductivity comparatively high in 40:60 and 50:50 concentrations, the percentage of moisture level moderately high in 50:50 concentration of vermicompost than other concentrations, The percentage of organic carbon, Nitrogen, Phosphorous, Potassium, Sodium, Calcium and Magnesium high in 50:50 concentration of vermicompost than other concentrations. Sulphur content significantly high in control while compare to other different concentrations which described in Table 1. Results of nutrient composition of vermicompost rubbish shows range of $\mathrm{pH}$ slightly acidic condition in control, 40:60 and neutral $\mathrm{pH}$ observed in $50: 50,60: 40$ concentration of vermicompost rubbish, Electrical conductivity comparatively high in 60:40 concentrations, percentage of moisture level moderately high in 50:50 concentration of vermicompost than other concentrations and control, Percentage of organic carbon, Nitrogen, Phosphorous, Potassium, Sodium, Calcium and Magnesium high in 50:50 concentration of vermicompost than other concentrations. Sulphur content notably high. Vermicompost plays a major role in improving growth and yield of different field crops. Darwin (1881) mentioned that earthworms prepare the ground in an excellent manner for the growth of fibrous rooted plants and for seedlings of all kinds. When earthworms are available in soil they always promote plant growth (Wollny, 1890; Hopp and Slater, 1948; Edwards and Lofty, 1980).

Number of leaves (6 to 8 leaves) and height of the plant $(12 \mathrm{~cm}$ to $13 \mathrm{~cm})$ were examined and they described in Table 2. After plantation of $30^{\text {th }}$ day flowers and fruits were not developed in all plants, number of leaves and height of plant highly increased in all plants including control, 50:50 vermicompost applied tomato plants shows more leaves $(17 \pm 1.94)$ and increasing height $(46 \pm 3.95)$, after $60^{\text {th }}$ day, flowers and fruits were developed in all plants. Number of leaves and height were highly increased, number of flowers, number of fruits are developed in all plants including control, 50:50 vermicompost applied tomato plant shows more leaves $(38 \pm 5.85)$ and increasing pattern of height $(68 \pm 5.39)$, number of flower $(26 \pm 7.22)$ and number of fruits $(11 \pm 2.56)$ also observed higher than other concentrations of vermicompost i.e., 40:60 (34 \pm 6.24 leaves, $62 \pm 6.64 \mathrm{~cm}$ height, $22 \pm 8.31$ number of flowers and $9 \pm 3.93$ number of fruits) and 60:40 (37 \pm 4.33 leaves, $59 \pm 5.25 \mathrm{~cm}$ height, $25 \pm 5.02$ number of flowers and $9 \pm 5.27$ number of fruits). In $90^{\text {th }}$ day of plantation, Number of leaves were observed from $44 \pm 5.69$ to $47 \pm 4.25$ and height of the plant was observed from $72 \pm 6.21 \mathrm{~cm}$ to $89 \pm 5.79$ $\mathrm{cm}$, they were highly increased from previous months, number of flowers $(28 \pm 4.81$ to $36 \pm 10.54)$, number of fruits $(15 \pm 4.53$ to $19 \pm 8.93)$ are developed in all plants including control plants, weight of the fruits also measured and recorded $(1226 \pm 45.03$ to 1876 \pm 93.52$)$; among these 50:50 vermicompost applied tomato plants shows more leaves $(47 \pm 4.25)$ and the increasing pattern of height $(89 \pm 5.79)$, number of flowers $(36 \pm 10.54)$, number of fruits $(19 \pm 8.93)$ and weight of the fruit (1876 \pm 93.52$)$ also yielded higher than other plot plants i.e., 40:60 (47 \pm 7.98 leaves, $83 \pm 4.99 \mathrm{~cm}$ height, $34 \pm 7.32$ number of flowers and $15 \pm 6.90$ number of fruits, weight of the fruits $1563 \pm 84.75 \mathrm{~g}$ ) and $60: 40$ (45 \pm 6.06 leaves, $85 \pm 6.84 \mathrm{~cm}$ height, $34 \pm 5.96$ number of flowers and $18 \pm 6.35$ number of fruits, weight of the fruits $1639 \pm 65.29 \mathrm{~g}$ ).

It has been observed that growth parameters such as root length, shoot length, intermodal 
length, leaf area, number of nodules and plant biomass were higher in vermicompost and farmyard manure treated plants. Similarly, the biochemical contents such as chlorophyll and protein were also found to be higher in the same treatment. Muhammad et al., (2017) observed that the growth attributes such as height, root length, fresh and dry weight of shoot and root numbers, length, width and LAI, number of branches, lateral roots and number of root nodules and yield attributes such as number of pods, number of grain and total gain weight (per plant) of the plant, black gram (Vigna mungo L.Hepper) were found to be significantly increased in the vermicompost treated plots compared to Farmyard manure and NPK treated plots.

After the plantation of $30^{\text {th }}$ dayS number of leaves $(14 \pm 2.82$ to $18 \pm 2.01)$ and height of the plant $(33 \pm 2.35 \mathrm{~cm}$ to $47 \pm 4.27 \mathrm{~cm})$ were highly increased in all plants including control plants, among these 50:50 vermicompost rubbish applied tomato plant shows more leaves $(18 \pm 2.01)$ and the increasing pattern of height $(47 \pm 4.27)$ than other concentrations of vermicompost rubbish i.e., 40:60 (16 \pm 1.39 leaves and $33 \pm 2.35 \mathrm{~cm}$ height) and 60:40 (17 \pm 3.31 leaves and $41 \pm 3.34 \mathrm{~cm}$ height). In $60^{\text {th }}$ day plants, flowers and fruits were developed and the number of leaves $(26 \pm 5.73$ to $36 \pm 1.79)$ and height of the plant $(43 \pm 7.24 \mathrm{~cm}$ to $65 \pm 3.56$ $\mathrm{cm})$ were highly increased, number of flowers $(12 \pm 3.58$ to $23 \pm 2.63)$, number of fruits $(7 \pm 1.54$ to $14 \pm 3.45)$ are developed in all plants including control plants, among these 50:50 vermicompost rubbish applied tomato plant shows more leaves $(36 \pm 1.79)$ and increasing pattern of height $(65 \pm 3.56)$, number of flowers $(23 \pm 2.63)$ and number of fruits (14 \pm 3.45$)$ also yielded higher than other concentrations of vermicompost rubbish i.e., 40:60 (36 \pm 5.94 leaves, $61 \pm 4.98 \mathrm{~cm}$ height, $19 \pm 3.67$ number of flowers and $11 \pm 2.82$ number of fruits) and 60:40 (35 \pm 2.50 leaves,
$63 \pm 6.31 \mathrm{~cm}$ height, $23 \pm 7.24$ number of flowers and $10 \pm 7.18$ number of fruits). In $90^{\text {th }}$ days, number of leaves $(43 \pm 3.72$ to $48 \pm 8.10)$ and height of the plant $(68 \pm 3.53 \mathrm{~cm}$ to $88 \pm 6.73 \mathrm{~cm}$ ) were highly increased, number of flowers $(23 \pm 3.38$ to $38 \pm 9.93)$, number of fruits $(13 \pm 5.56$ to $17 \pm 5.19)$ are developed in all plants including control plants, weight of the fruits also measured and recorded $(1161 \pm 53.83$ to $1683 \pm 98.36)$; among these 50:50 vermicompost rubbish applied tomato plant shows more leaves $(48 \pm 8.10)$, plant height (88 \pm 6.73$)$, number of flowers $(38 \pm 9.93)$, number of fruits $(17 \pm 5.19)$ and weight of the fruits $(1683 \pm 98.36)$ also yielded higher than other concentrations of vermicompost rubbish i.e., 40:60 (44 \pm 3.13 leaves, $83 \pm 2.87 \mathrm{~cm}$ height, $31 \pm 8.25$ number of flower and $15 \pm 8.38$ number of fruits, weight of the fruits $1376 \pm 58.93 \mathrm{~g}$ ) and 60:40 (42 \pm 7.46 leaves, $84 \pm 5.92 \mathrm{~cm}$ height, $37 \pm 4.27$ number of flowers and $16 \pm 4.64$ number of fruits, weight of the fruits $1545 \pm 54.34 \mathrm{~g}$ ).

Increase in yield parameters and yield of soybean due to vermicompost application was reported by Venkatakrishnan and Balasubramanian (1996). Maynard (1995), who reported that tomato yield in field soils amended with compost were significantly greater than those in the untreated plots. Edwards (1995) reported that in a Rothamsted study with 25 types of vegetables, fruits or ornamentals, earthworm cast performed better than compost or commercial potting mixture amendments. Nainawatt (1997) found that the application of vermicompost to two cultivars of wheat- Raj 3077 and Raj 1482 resulted in higher total dry matter production and increased grain yield in comparison to organic manure and chemical fertilizers. Rani and Srivastava (1997) tested vermicompost for its ability to replace a proportion of the urea fertilizer, supplying one third to one quarter of $\mathrm{N}$ as vermicompost increased plant height, grain yield and yield components of rice. 
Integrated application of organic $\mathrm{N}$ through vermicompost, fertilizer $\mathrm{N}$ and bio-fertilizer enhanced the growth parameters, yield attributes and yield of rice.

Nagarajan (1997) obtained higher net income by application of vermicompost in rice. Sainz et al., (1988) reported that addition of vemicompost to soil resulted in increased mineral contents in the substrate and higher concentrations $\mathrm{P}, \mathrm{Ca}, \mathrm{Mg}, \mathrm{Cu}, \mathrm{Mn}$ and $\mathrm{Zn}$ in shoot tissue of red clover and $\mathrm{Zn}$ in shoot tissues of red clover and cucumber. Vermicompost has been shown to promote growth of a wide range of cereals, vegetables, ornamentals plants etc. (Kale, 1998) reported that integration of vermicompost with inorganic fertilizer tended to increase the yield of crops viz. potato, rape seed, mulberry and marigold over that with traditional compost prepared from the same substrate.

Application of vermicompost produced herbage yields of coriander cultivars that were comparable to those obtained with chemical fertilizers. Growth of tomato plants (Lycopersicum esculentum Mill) in three kinds of horticultural potting media mixed with various concentrations of vermicomposted pig manure was assessed by Atiyeh et al., (1999).

The fresh weight of flowers such as Chrysanthemum chinensis increased with the application of different levels of vermicompost. Also, the number of flowers per plant, flower diameter and yield were maximum with the applications of 10 tones per hectare of vermicompost along with $50 \%$ of recommended dose of NPK fertilizer. However, the vase life of flowers was high with the combined applications of vermicompost at 15 tones per Hectare and $50 \%$ of recommended dose of NPK fertilizer (Nethra et al., 1999). They stated that the application of vermicompost along with fertilizer $\mathrm{N}$ gave higher dry matter (16.2g plant $^{-1}$ and grain yield (3.6 tones per Hecate) of wheat (Triticum aestivm) and higher dry matter yield $\left(0.66 \mathrm{~g}\right.$ plant $\left.^{-1}\right)$ of the following coriander (Coriandrum sativum) crop in sequential cropping system. Similarly, a positive response was obtained with the application of vermicompost to other field crops such as sorghum (Sorghum bicolor) (Patil and Sheelavantar, 2000).

The physicochemical properties of available nutrients in the soil before and after cultivation of vermicompost applied tomato plants such as $\mathrm{pH}$, Electrical conductivity, Moisture, Organic Carbon, Nitrogen, Phosphorous, Potassium, Sodium, Sulphur, Calcium, Magnesium and $\mathrm{C}: \mathrm{N}$ ratio were increased in all three experimental plots (40:60, 50:50 and 60:40) after cultivation, compared with control plot.

Among these three concentrations, the nutrient level was observed significantly high in 50:50 concentrations. The range of nutrients was $\mathrm{pH}(7.1 \pm 0.03)$, Electrical conductivity $(0.13 \pm 0.00)$, Moisture $(76 \pm 4.30)$, Organic Carbon (8.99 \pm 0.24$)$, Nitrogen (0.52 \pm 0.05$), \quad$ Phosphorous $\quad(0.41 \pm 0.01)$, Potassium (0.73 \pm 0.02$)$, Sodium $(0.91 \pm 0.02)$, Sulphur (1.46 \pm 0.03$)$, Calcium $(0.45 \pm 0.07)$, Magnesium (1.23 \pm 0.05$)$ and C:N (10:1).

The physicochemical properties of available nutrients in the soil before and after cultivation of vermicompost rubbish applied tomato plants such as $\mathrm{pH}$, Electrical conductivity, Moisture, Organic Carbon, Nitrogen, Phosphorous, Potassium, Sodium, Sulphur, Calcium, Magnesium and C:N ratio were increased in all three experimental plots (40:60, 50:50 and 60:40) after cultivation, compared with control plot. Among these three concentrations, the nutrient level was observed significantly high in 50:50 concentrations. 
Table.1 Nutrition value of vermicompost and vermicompost rubbish

\begin{tabular}{|c|c|c|c|c|c|c|c|c|}
\hline \multirow{2}{*}{$\begin{array}{l}\text { Name of the } \\
\text { parameter }\end{array}$} & \multicolumn{4}{|c|}{ Different concentration of vermicompost } & \multicolumn{4}{|c|}{ Different concentration of vermicompost rubbish } \\
\hline & Control & $40: 60$ & $50: 50$ & $60: 40$ & Control & $40: 60$ & $50: 50$ & $60: 40$ \\
\hline pH & $6.8 \pm 0.16$ & $6.66 \pm 0.24$ & $7.06 \pm 0.32$ & $7.13 \pm 0.47$ & $6.42 \pm 0.14$ & $6.81 \pm 0.16$ & $7.02 \pm 0.17$ & $7.31 \pm 0.18$ \\
\hline $\begin{array}{l}\text { Electrical } \\
\text { conductivity } \\
\left(\mathrm{dSm}^{-1}\right)\end{array}$ & $0.49 \pm 0.01$ & $0.52 \pm 0.02$ & $0.52 \pm 0.02$ & $0.51 \pm 0.01$ & $0.21 \pm 0.01$ & $0.21 \pm 0.01$ & $0.23 \pm 0.02$ & $0.24 \pm 0.02$ \\
\hline Moisture (\%) & $21.7 \pm 0.41$ & $23.5 \pm 0.52$ & $25.93 \pm 0.49$ & $24.86 \pm 0.53$ & $23.5 \pm 0.35$ & $24.6 \pm 0.46$ & $26.85 \pm 0.46$ & $25.74 \pm 0.47$ \\
\hline $\begin{array}{l}\text { Total Organic } \\
\text { carbon }(\%)\end{array}$ & $12.33 \pm 0.28$ & $13.34 \pm 0.35$ & $13.38 \pm 0.41$ & $13.02 \pm 0.32$ & $12.43 \pm 0.18$ & $13.83 \pm 0.7$ & $13.89 \pm 0.27$ & $13.16 \pm 0.2$ \\
\hline $\begin{array}{l}\text { Total Nitrogen } \\
(\%)\end{array}$ & $1.630 \pm 0.07$ & $1.72 \pm 0.03$ & $1.84 \pm 0.02$ & $1.81 \pm 0.02$ & $1.21 \pm 0.07$ & $1.65 \pm 0.05$ & $1.73 \pm 0.08$ & $1.36 \pm 0.06$ \\
\hline $\begin{array}{l}\text { Total } \\
\text { Phosphorous (\%) }\end{array}$ & $1.21 \pm 0.06$ & $1.35 \pm 0.08$ & $1.75 \pm 0.02$ & $1.48 \pm 0.03$ & $1.21 \pm 0.03$ & $1.06 \pm 0.04$ & $1.43 \pm 0.05$ & $1.41 \pm 0.02$ \\
\hline $\begin{array}{l}\text { Total Potassium } \\
(\%)\end{array}$ & $0.97 \pm 0.00$ & $1.23 \pm 0.03$ & $1.64 \pm 0.34$ & $1.45 \pm 0.04$ & $0.93 \pm 0.01$ & $1.27 \pm 0.06$ & $1.40 \pm 0.06$ & $1.35 \pm 0.02$ \\
\hline Total Sodium (\%) & $1.37 \pm 0.08$ & $1.54 \pm 0.04$ & $1.78 \pm 0.02$ & $1.42 \pm 0.07$ & $1.39 \pm 0.05$ & $1.45 \pm 0.06$ & $1.64 \pm 0.04$ & $1.38 \pm 0.07$ \\
\hline Total sulphur (\%) & $2.61 \pm 0.29$ & $2.18 \pm 0.25$ & $2.34 \pm 0.28$ & $2.42 \pm 0.31$ & $2.59 \pm 0.14$ & $2.13 \pm 0.15$ & $2.26 \pm 0.09$ & $2.37 \pm 0.08$ \\
\hline $\begin{array}{l}\text { Total Calcium } \\
(\%)\end{array}$ & $1.34 \pm 0.04$ & $1.46 \pm 0.03$ & $1.79 \pm 0.07$ & $1.72 \pm 0.02$ & $1.21 \pm 0.07$ & $1.35 \pm 0.06$ & $1.74 \pm 0.04$ & $1.69 \pm 0.02$ \\
\hline $\begin{array}{l}\text { Total Magnesium } \\
(\%)\end{array}$ & $1.56 \pm 0.03$ & $1.46 \pm 0.04$ & $1.75 \pm 0.02$ & $1.75 \pm 0.03$ & $1.34 \pm 0.05$ & $1.48 \pm 0.03$ & $1.82 \pm 0.07$ & $1.41 \pm 0.01$ \\
\hline $\mathrm{C}: \mathrm{N}$ ratio & $1: 12$ & $1: 13$ & $1: 13$ & $1: 13$ & $1: 12$ & $1: 13$ & $1: 13$ & $1: 13$ \\
\hline
\end{tabular}


Table.2 Growth and yielding pattern of tomato plant by using vermicompost and vermicompost rubbish

\begin{tabular}{|c|c|c|c|c|c|c|c|c|c|c|}
\hline \multirow[t]{2}{*}{$\begin{array}{c}\text { Different } \\
\text { concentration }\end{array}$} & $\begin{array}{l}\text { No. of } \\
\text { leaves }\end{array}$ & $\begin{array}{c}\text { Plant } \\
\text { height } \\
(\mathrm{cm})\end{array}$ & $\begin{array}{c}\text { Number } \\
\text { of } \\
\text { flowers }\end{array}$ & $\begin{array}{l}\text { Number } \\
\text { of fruits }\end{array}$ & $\begin{array}{l}\text { Weight of } \\
\text { the fruits } \\
\text { (g) }\end{array}$ & $\begin{array}{l}\text { No. of } \\
\text { leaves }\end{array}$ & $\begin{array}{c}\text { Plant } \\
\text { height } \\
\text { (cm) }\end{array}$ & $\begin{array}{c}\text { Number } \\
\text { of } \\
\text { flowers }\end{array}$ & $\begin{array}{l}\text { Number } \\
\text { of fruits }\end{array}$ & $\begin{array}{l}\text { Weight of } \\
\text { the fruits } \\
\text { (g) }\end{array}$ \\
\hline & \multicolumn{5}{|c|}{ Application of vermicompost } & \multicolumn{5}{|c|}{ Application of vermicompost rubbish } \\
\hline \multicolumn{11}{|c|}{ During the sapling sowing } \\
\hline Control & $7 \pm 0.54$ & $12 \pm 1.32$ & $0 \pm 0.00$ & $0 \pm 0.00$ & $0 \pm 0.00$ & $5 \pm 1.67$ & $10 \pm 1.75$ & $0 \pm 0.00$ & $0 \pm 0.00$ & $0 \pm 0.00$ \\
\hline $40: 60$ & $6 \pm 0.36$ & $13 \pm 1.58$ & $0 \pm 0.00$ & $0 \pm 0.00$ & $0 \pm 0.00$ & $6 \pm 1.45$ & $14 \pm 0.89$ & $0 \pm 0.00$ & $0 \pm 0.00$ & $0 \pm 0.00$ \\
\hline $50: 50$ & $7 \pm 0.63$ & $13 \pm 1.30$ & $0 \pm 0.00$ & $0 \pm 0.00$ & $0 \pm 0.00$ & $6 \pm 0.92$ & $11 \pm 0.91$ & $0 \pm 0.00$ & $0 \pm 0.00$ & $0 \pm 0.00$ \\
\hline $60: 40$ & $8 \pm 0.71$ & $12 \pm 2.95$ & $0 \pm 0.00$ & $0 \pm 0.00$ & $0 \pm 0.00$ & $7 \pm 1.94$ & $10 \pm 1.05$ & $0 \pm 0.00$ & $0 \pm 0.00$ & $0 \pm 0.00$ \\
\hline \multicolumn{11}{|c|}{ In $30^{\text {th }}$ day } \\
\hline Control & $13 \pm 2.58$ & $35 \pm 4.92$ & $0 \pm 0.00$ & $0 \pm 0.00$ & $0 \pm 0.00$ & $14 \pm 2.82$ & $33 \pm 2.35$ & $0 \pm 0.00$ & $0 \pm 0.00$ & $0 \pm 0.00$ \\
\hline $40: 60$ & $14 \pm 2.45$ & $42 \pm 3.14$ & $0 \pm 0.00$ & & & $16 \pm 1.39$ & $45 \pm 5.00$ & $0 \pm 0.00$ & & \\
\hline $50: 50$ & $17 \pm 1.94$ & $46 \pm 3.95$ & $0 \pm 0.00$ & $0 \pm 0.00$ & $0 \pm 0.00$ & $18 \pm 2.01$ & $47 \pm 4.27$ & $0 \pm 0.00$ & $0 \pm 0.00$ & $0 \pm 0.00$ \\
\hline $60: 40$ & $16 \pm 3.01$ & $39 \pm 2.53$ & $0 \pm 0.00$ & $0 \pm 0.00$ & $0 \pm 0.00$ & $17 \pm 3.31$ & $41 \pm 3.34$ & $0 \pm 0.00$ & $0 \pm 0.00$ & $0 \pm 0.00$ \\
\hline \multicolumn{11}{|c|}{ In $60^{\text {th }}$ day } \\
\hline Control & $31 \pm 4.91$ & $53 \pm 8.41$ & $16 \pm 3.50$ & $6 \pm 2.40$ & $0 \pm 0.00$ & $26 \pm 5.73$ & $43 \pm 7.24$ & $12 \pm 3.58$ & $7 \pm 1.54$ & $0 \pm 0.00$ \\
\hline $40: 60$ & $34 \pm 6.24$ & $62 \pm 6.64$ & $22 \pm 8.31$ & $9 \pm 3.93$ & $0 \pm 0.00$ & $36 \pm 5.94$ & $61 \pm 4.98$ & $19 \pm 3.67$ & $11 \pm 2.82$ & $0 \pm 0.00$ \\
\hline $50: 50$ & $38 \pm 5.85$ & $68 \pm 5.39$ & $26 \pm 7.22$ & $11 \pm 2.56$ & $0 \pm 0.00$ & $36 \pm 1.79$ & $65 \pm 3.56$ & $23 \pm 2.63$ & $14 \pm 3.45$ & $0 \pm 0.00$ \\
\hline $60: 40$ & $37 \pm 4.33$ & $59 \pm 5.25$ & $25 \pm 5.02$ & $9 \pm 5.27$ & $0 \pm 0.00$ & $35 \pm 2.50$ & $63 \pm 6.31$ & $23 \pm 7.24$ & $10 \pm 7.18$ & $0 \pm 0.00$ \\
\hline \multicolumn{11}{|c|}{ In $90^{\text {th }}$ day } \\
\hline Control & $44 \pm 5.69$ & $72 \pm 6.21$ & $28 \pm 4.81$ & $15 \pm 4.53$ & $1226 \pm 45.03$ & $43 \pm 3.72$ & $68 \pm 3.53$ & $23 \pm 3.38$ & $13 \pm 5.56$ & $1161 \pm 53.83$ \\
\hline $40: 60$ & $47 \pm 7.98$ & $83 \pm 4.99$ & $34 \pm 7.32$ & $15 \pm 6.90$ & $1563 \pm 84.75$ & $44 \pm 3.13$ & $83 \pm 2.87$ & $31 \pm 8.25$ & $15 \pm 8.38$ & $1376 \pm 58.93$ \\
\hline $50: 50$ & $47 \pm 4.25$ & $89 \pm 5.79$ & $36 \pm 10.54$ & $19 \pm 8.93$ & $1876 \pm 93.52$ & $48 \pm 8.10$ & $88 \pm 6.73$ & $38 \pm 9.93$ & $17 \pm 5.19$ & $1683 \pm 98.36$ \\
\hline $60: 40$ & $45 \pm 6.06$ & $85 \pm 6.84$ & $34 \pm 5.96$ & $18 \pm 6.35$ & $1639 \pm 65.29$ & $42 \pm 7.46$ & $84 \pm 5.92$ & $37 \pm 4.27$ & $16 \pm 4.64$ & $1545 \pm 54.34$ \\
\hline
\end{tabular}

\# Mean and standard deviations were obtained from 5 individuals 
Table.3 Physicochemical properties of cultivated plot soil before and after cultivation of tomato plant

\begin{tabular}{|c|c|c|c|c|c|c|c|c|c|c|}
\hline \multirow{2}{*}{$\begin{array}{l}\text { Name of the } \\
\text { parameter }\end{array}$} & \multirow{2}{*}{$\begin{array}{l}\text { Before apply } \\
\text { the } \\
\text { vermicompost }\end{array}$} & \multicolumn{4}{|c|}{ After apply the vermicompost } & \multirow{2}{*}{$\begin{array}{l}\text { Before apply } \\
\text { the } \\
\text { vermicompost } \\
\text { rubbish }\end{array}$} & \multicolumn{4}{|c|}{ After apply the vermicompost rubbish } \\
\hline & & Control & 40:60 & $50: 50$ & $60: 40$ & & Control & $40: 60$ & $50: 50$ & $60: 40$ \\
\hline pH & $6.2 \pm 0.14$ & $6.4 \pm 0.14$ & $7.1 \pm 0.21$ & $7.1 \pm 0.03$ & $6.8 \pm 0.18$ & $6.2 \pm 0.14$ & $6.8 \pm 0.36$ & $6.49 \pm 0.86$ & $7.1 \pm 0.15$ & $6.8 \pm 0.22$ \\
\hline $\begin{array}{l}\text { Electrical } \\
\text { conductivity }\end{array}$ & $0.11 \pm 0.00$ & $0.11 \pm 0.00$ & $0.14 \pm 0.00$ & $0.13 \pm 0.00$ & $0.13 \pm 0.00$ & $0.12 \pm 0.00$ & $0.13 \pm 0.00$ & $0.12 \pm 0.00$ & $0.13 \pm 0.00$ & $0.13 \pm 0.00$ \\
\hline Moisture & $55 \pm 3.58$ & $63 \pm 4.35$ & $71 \pm 4.54$ & $76 \pm 4.30$ & $74 \pm 2.59$ & $58 \pm 2.75$ & $64 \pm 7.32$ & $70 \pm 2.86$ & $72 \pm 2.70$ & $71 \pm 4.85$ \\
\hline $\begin{array}{l}\text { Total } \\
\text { Organic } \\
\text { Carbon }\end{array}$ & $7.21 \pm 0.33$ & $7.94 \pm 0.35$ & $8.22 \pm 0.48$ & $8.99 \pm 0.24$ & $8.73 \pm 0.15$ & $7.65 \pm 0.32$ & $7.12 \pm 0.83$ & $8.45 \pm 0.37$ & $9.36 \pm 0.63$ & $9.35 \pm 0.17$ \\
\hline $\begin{array}{l}\text { Total } \\
\text { Nitrogen }\end{array}$ & $0.33 \pm 0.02$ & $0.45 \pm 0.01$ & $0.51 \pm 0.06$ & $0.52 \pm 0.05$ & $0.52 \pm 0.03$ & $0.37 \pm 0.06$ & $0.45 \pm 0.04$ & $0.54 \pm 0.02$ & $0.62 \pm 0.03$ & $0.57 \pm 0.03$ \\
\hline $\begin{array}{l}\text { Total } \\
\text { Phosphorous }\end{array}$ & $0.21 \pm 0.02$ & $0.23 \pm 0.01$ & $0.32 \pm 0.02$ & $0.41 \pm 0.01$ & $0.35 \pm 0.02$ & $0.23 \pm 0.03$ & $0.27 \pm 0.02$ & $0.32 \pm 0.01$ & $0.38 \pm 0.03$ & $0.36 \pm 0.02$ \\
\hline $\begin{array}{l}\text { Total } \\
\text { Potassium }\end{array}$ & $0.41 \pm 0.04$ & $0.63 \pm 0.05$ & $0.70 \pm 0.03$ & $0.73 \pm 0.02$ & $0.62 \pm 0.09$ & $0.45 \pm 0.03$ & $0.58 \pm 0.07$ & $0.65 \pm 0.02$ & $0.72 \pm 0.04$ & $0.62 \pm 0.03$ \\
\hline $\begin{array}{l}\text { Total } \\
\text { Sodium }\end{array}$ & $0.81 \pm 0.08$ & $0.85 \pm 0.13$ & $0.87 \pm 0.11$ & $0.91 \pm 0.02$ & $0.88 \pm 0.00$ & $0.86 \pm 0.04$ & $0.91 \pm 0.02$ & $0.95 \pm 0.04$ & $0.97 \pm 0.05$ & $0.96 \pm 0.06$ \\
\hline $\begin{array}{l}\text { Total } \\
\text { sulphur }\end{array}$ & $0.95 \pm 0.14$ & $1.21 \pm 0.31$ & $1.37 \pm 0.08$ & $1.46 \pm 0.03$ & $1.25 \pm 0.32$ & $0.99 \pm 0.13$ & $1.25 \pm 0.31$ & $1.59 \pm 0.25$ & $1.72 \pm 0.28$ & $1.68 \pm 0.43$ \\
\hline $\begin{array}{l}\text { Total } \\
\text { Calcium }\end{array}$ & $0.34 \pm 0.05$ & $0.37 \pm 0.03$ & $0.41 \pm 0.01$ & $0.45 \pm 0.07$ & $0.35 \pm 0.09$ & $0.35 \pm 0.03$ & $0.39 \pm 0.04$ & $0.47 \pm 0.03$ & $0.52 \pm 0.02$ & $0.48 \pm 0.03$ \\
\hline $\begin{array}{l}\text { Total } \\
\text { Magnesium }\end{array}$ & $0.36 \pm 0.11$ & $0.58 \pm 0.00$ & $0.74 \pm 0.13$ & $1.23 \pm 0.05$ & $1.22 \pm 0.03$ & $0.37 \pm 0.04$ & $0.56 \pm 0.05$ & $0.68 \pm 0.12$ & $0.73 \pm 0.03$ & $0.91 \pm 0.03$ \\
\hline C:N ratio & $7: 1$ & $8: 1$ & $10: 1$ & 10:1 & $9: 1$ & $7: 1$ & $8: 1$ & $10: 1$ & 10:1 & $9: 1$ \\
\hline
\end{tabular}


The range of nutrients was $\mathrm{pH}(7.1 \pm 0.15)$, Electrical conductivity $(0.13 \pm 0.00)$, Moisture (72 $\pm 2.7072 \pm 2.70)$, Organic Carbon (9.36 \pm 0.63$), \quad$ Nitrogen $\quad(0.62 \pm 0.03)$, Phosphorous $\quad(0.38 \pm 0.03), \quad$ Potassium (0.72 \pm 0.04$)$, Sodium $(0.97 \pm 0.05)$, Sulphur (1.72 \pm 0.28$), \quad$ Calcium $\quad(0.52 \pm 0.02)$, Magnesium $(0.73 \pm 0.03)$ and $\mathrm{C}: \mathrm{N}(10: 1)$, the detailed values are given in Table 3. Edwards and Lofty (1975) showed that addition of typical field population of $L$. terrestris, A. longa, A. clorotica and A. caliginosa to soil dug out as intact profiles and not cultivated, greatly increased the emergence and growth of barely seedlings. Sainz et al., (1998) reported that addition of vemicompost to soil resulted increased mineral contents. Kumari and Ushakumari (2002) suggested that treatment with enriched vermicompost was superior to other treatments. Subler et al., (1998) incorporation of small amount (10\%) of pig manure vermicompost into commercial bedding plant potting media sufficient to produce a significant increase in the total biomass of tomato seedlings in the greenhouse.

It could be concluded from present investigation that amongst the various combinations of vermicompost and vermicompost rubbish 50:50 concentration sows excellent growth and yield parameter on tomato plants in field condition. Eudrilus euginae species of earthworm was found superior on production of vermicompost. Vermicompost significantly affected tomato plant growth and yield. The present results are in accordance with earlier studies carried out by Pritam et al., (2010). Vermicompost and vermicompost rubbish increases the quality in soil.

\section{References}

Atiyeh, R.M. Edwards, C.A. Metzer, J.D. Lee. S. Arancon, N.Q. 2002. The influence of humic acids derived from earthworm-processed organic wastes on plant growth. Bioresour Technol 84:714.

Atiyeh, R.M. Subler, S. Edwards, C.A. Metzger, J.D. 1999. Growth of tomato plants in horticultural media amended with vermicompost. Pedobiologia 43, 724-728.

Darwin, C.R. 1881. The formation of vegetable mould. Through the action of worms, with observation on their habits. London; John Murray.

Edwards, C. A. 1995. Earthworm. McGrawHill Encyclopedia, 81-83.

Edwards, C.A. and Lofty, J.R. 1980. Effects of earthworm inoculation upon the root growth of direct drilled cereals. J. Appl. Ecol. 17: 533-543.

Follet, R.H. Murphy, L.S. Donahue, R.L. 1981. Fertilizer and soil amendments. Prentice Hall Inc. Englewood. New Jersey.

Hopp, H. and Slater, C.S. 1949. The effect of earthworms on the productivity of agricultural soil. J. Agric. Res. 78: 325339.

Kale, R. D. 1998. Earthworm Cinderella of Organic Farming. Prism Book Pvt Ltd, Bangalore, India. $88 \mathrm{pp}$.

Kumari, M.S. and Ushakumari, K. 2002. Effect of vermicompost enriched with rock phosphate on the yield and uptake of nutrients in cowpea (Vigna unguiculata L. Walp). J. Trop. Agric, 40, pp.27-30.

Lavelle, P. and Martin, A. 1992. Small-scale and large-scale effects of endogenic earthworms on soil organic matter dynamics in soils of the humid tropics. Soil Biology and Biochemistry, 24, 1491- 1498

Maynard, A. A. 1995. Cumulative effects of annual addition of MSW compost on the yield of field-grown tomatoes. Compost Science \& Utilization 3(2): 
$47-54$.

Muhammad Iqbal1, Naveed Iqbal Raja1, ZiaUr-Rehman Mashwani1, Mubashir Hussain1, Muhammad Ejaz1, Farhat Yasmeen. 2017. Effect of Silver Nanoparticles on Growth of Wheat Under Heat Stress. Iranian journal of science and technology. transaction a, science $\cdot 10.1007 / \mathrm{s}$ 40995-017-0417-4.

Nagarajan, S. 1997. Kisan World, 24(8): 4950.

Nainawatt R. 1997. Vermitechnological studies on organic solid waste management. Ph.D. Thesis, Rajasthan University, India.

Nethra, N.N. Jayaprasad, K.V. and Kale, R.D. 1999. China aster [Callistephus chinensis (L)] cultivation using vermicompost as organic amendment. Crop Research, Hisar 17(2): 209-215.

Patil, S.L. and Sheelavantar, M.N. 2000. Effect of moisture conservation practices, organic sources and nitrogen levels on yield, water use and root development of rabi sorghum [Sorghum bicolor (L.)] in the vertisols of semiarid tropics. Annals of Agricultural Research 21(21):32-36.

Pritam, S. Garg, V.K. Kaushik, C.P. 2010. Growth and yield response of marigold to potting media containing vermi compost produced from different wastes. Environmentalist, 30; 123-130.

Rakesh Joshi and Adarsh Pal Vig, 2010. Effect of Vermicompost on Growth, Yield and Quality of Tomato
(Lycopersicum esculentum L). African Journal of Basic \& Applied Sciences 2 (3-4): 117-123.

Rani, R. and Srivastava, O.P. 1997. nt. Rice Res. Notes. 22(3): 30-31.

Sáinz, J.C. Maeda-Martínez, A.N. Ascencio, F. 1998. Experimental vibriosis induction with Vibrio alginolyticus of larvae of the Catarina scallop (Argopecten ventricosus $=$ circularis) (Sowerby II, 1842). Microb Ecol 35:188-192.

Sainz, M. Taboada-Castro, M. Vilariño, A. 1998. Growth, mineral nutrition and mycorrhizal colonization of red clover and cucumber plants grown in a soil amended with composted urban wastes. Plant Soil, 205: 85-92.

Subler, S., Edwards, C. A., Metzger, J. 1998. Comparing composts and vermicomposts. Bio Cycle 39, 63-66.

Tandon, H. 2005. Methods of analysis of soils, plants, water, fertilizers \&organic manures, Fertilizer Development and consultation organization, Bhanot Corner, Pamposh Enclave, New Delhi, India.

Venkatakrishnan and Balasubramanian. 1996. Yield maximization in sunflower. Madras Agric, J., 83(12): 791-792.

Wollny, E. 1890. Untersuchungen Uber die Beeinflussung der Fruchtbarkeit der Acker Krume durch die Tatig Keit der Regenwurmer. Forschn Geb. Agrik Phys. Bodenk. 13: 381-395.

\section{How to cite this article:}

Sundararasu, K. 2019. Growth and Yield Effects of Vermicompost and Vermicompost Rubbish on Selected Vegetable Crop. Int.J.Curr.Microbiol.App.Sci. 8(02): 975-984.

doi: https://doi.org/10.20546/ijcmas.2019.802.113 